Archive for

Organic Chemistry

Arkivoc 2019, part v, 96-107

\title{
Synthesis and biological studies of new quinazolines with ether functions in position 2
}

Dabbugoddu Brahmaiah,, ${ }^{a, b}$ Anagani Kanaka Durga Bhavani, *c Pasula Aparna, ${ }^{a}$ Nangunoori Sampath Kumar, ${ }^{a}$ Hélène Solhi, ${ }^{d}$ Rémy Le Guevel, ${ }^{d}$ Blandine Baratte, ${ }^{e}$ Sandrine Ruchaud, ${ }^{e}$ Stéphane Bach, ${ }^{e}$ Paul Mosset, ${ }^{f}$ and René Grée*f

a Chemveda Life Sciences India Pvt. Ltd., \#B-11/1, IDA Uppal, Hyderabad-500039, Telangana, India b Jawaharlal Nehru Technological University Hyderabad, Kukatpally, Hyderabad-500 085, Telangana, India

c Osmania University, Department of Chemistry, Hyderabad 500007, Telangana, India

'Univ Rennes, Plateform ImPACcell, BIOSIT, F-35000 Rennes, France

e Sorbonne Université, CNRS, Plateforme de Criblage KISSf (Kinase Inhibitor Specialized Screening facility),

Protein Phosphorylation and Human Diseases Unit, Station Biologique de Roscoff, place G. Tessier, 29688 Roscoff Cedex, France

f Univ Rennes, CNRS, ISCR (Institut des Sciences Chimiques de Rennes), UMR 6226, F-35000 Rennes, France Email: rene.gree@univ-rennes1.fr

Received 12-21-2018

Accepted 02-12-2019

Published on line $02-28-2019$

\section{Abstract}

A series of new quinazolines linked to triazoles through an ether chain in position 2 has been designed and synthetized through a flexible route. Cytotoxicity assays on selected cancer cell lines and inhibition studies toward a panel of representative mammalian kinases have been performed on these molecules.

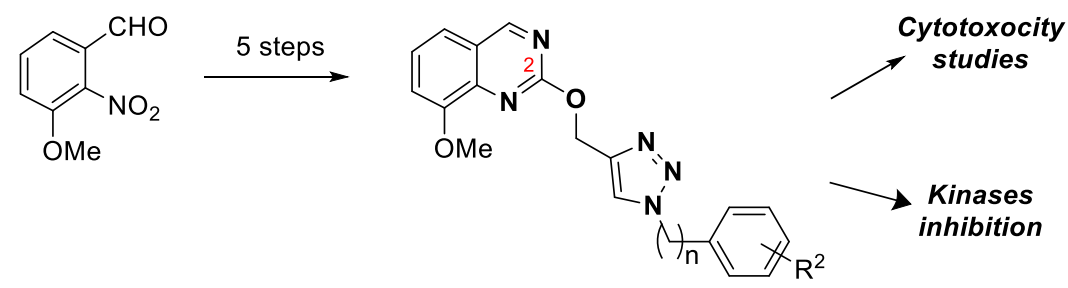

Keywords: Quinazolines, triazoles, cytotoxicity, kinases 


\section{Introduction}

Many quinazoline alkaloids and derivatives have been isolated already, and the antimalarial (+)- Febrifugine 1 and the cytotoxic Luotonin $\mathbf{A} \mathbf{2}$ are representative examples of this family of natural products (Figure 1). ${ }^{1}$ From a structural point of view, almost all of them possess a quinazoline-4(3H)-one ring system. On the other hand, the quinazoline nucleus is also a privilege scaffold found in the basic skeleton of various types of drugs and/or bioactive molecules. ${ }^{2-4}$ Representative examples are indicated in Figure 1 and it is worth noting that all compounds 3-8, which are potent kinase inhibitors used as anticancer drugs, have an aniline-type substituent in position 4 of this structure. Some other quinazolines, like Doxasocine 9 and Prazosin 10 (these two derivatives are used against hypertension) have both a primary amine in position 4 and a substituted piperazine in position 2 .<smiles>O=C(C[C@@H]1NCCCC1O)Cn1cnc2ccccc2c1=O</smiles>

1: (+)-Febrifugine

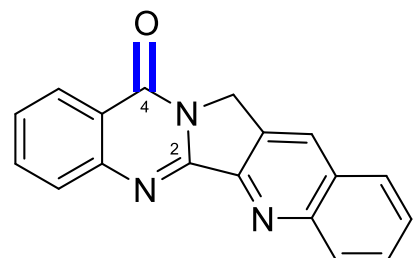

2: Luotonin A<smiles>[R]c1cc2ncnc(Nc3ccc(F)c(Cl)c3)c2cc1[R]</smiles>

3: Afanitib: $\mathrm{R}^{1}=-\mathrm{NHC}(\mathrm{O}) \mathrm{CH}=\mathrm{CHCH}_{2} \mathrm{NMe}_{2} ; \mathrm{R}^{2}=\mathrm{O}-\mathrm{THF}$

4: Canertinib: $\mathrm{R}^{1}=-\mathrm{NHC}(\mathrm{O}) \mathrm{CH}=\mathrm{CH}_{2} ; \mathrm{R}^{2}=\mathrm{O}-\mathrm{CH}_{2} \mathrm{CH}_{2}$-morpholine

5: Dacomitinib: $\mathrm{R}^{1}=-\mathrm{NHC}(\mathrm{O}) \mathrm{CH}=\mathrm{CHCH}_{2}$ piperidine; $\mathrm{R}^{2}=\mathrm{OMe}$

6: Gefitinib: $-\mathrm{O}\left(\mathrm{CH}_{2}\right)_{3}$-morpholine; $\mathrm{R}^{2}=\mathrm{OMe}$<smiles>[R]c1cc([R])c(Nc2ncnc3cc([R])c([R])cc23)cc1[R]</smiles>

7: Erlotinib: $\mathrm{R}^{1}=\mathrm{R}^{2}=-\mathrm{OCH}_{2} \mathrm{CH}_{2} \mathrm{OMe}$; $\mathrm{R}^{3}=\mathrm{R}^{4}=\mathrm{H} ; \mathrm{R}^{5}=\mathrm{C} \equiv \mathrm{CH}$ 8: Vandetanib: $\mathrm{R}^{1}=\mathrm{OMe} ; \mathrm{R}^{2}=-\mathrm{OCH}_{2}$-piperidine; $\mathrm{R}^{3}=\mathrm{F} ; \mathrm{R}^{4}=\mathrm{Br} ; \mathrm{R}^{5}=\mathrm{H}$<smiles>COc1cc2nc(N3CCN(C(=O)C4COc5ccccc5O4)CC3)nc(N)c2cc1OC(=O)OCc1ccccc1</smiles><smiles>COc1cc2nc(N3CCN(C(=O)c4ccco4)CC3)nc(N)c2cc1OC</smiles>

Figure 1. Representative examples of bioactive natural products and drugs with quinazoline cores.

Further, extensive literature search shows that much less is known about type-A molecules with $\mathbf{X}-\mathbf{R}^{\mathbf{1}}$ chains in position 2 ( $\mathbf{X}$ being heteroatom like $\mathrm{O}, \mathrm{S}$ and $\mathbf{N}$ and $\mathbf{R}^{\mathbf{1}}=$ alkyl or substituted alkyl chains, aromatics, heteroaromatics.....) (Figure 2). Therefore, we embarked on a program involving the synthesis and biological evaluation of such derivatives. The goal of this paper is to report the first part of this research, dealing with the 
synthesis of a focused library of oxygen-linked molecules $\mathbf{1 1}$ with a short linker and triazoles in terminal position. The choice of the triazole nucleus is based upon the fact that this core structure is found also in many biologically active molecules. ${ }^{5}$<smiles>[R1]c1ncc2cc[R1]cc2n1</smiles>

$\boldsymbol{A}$

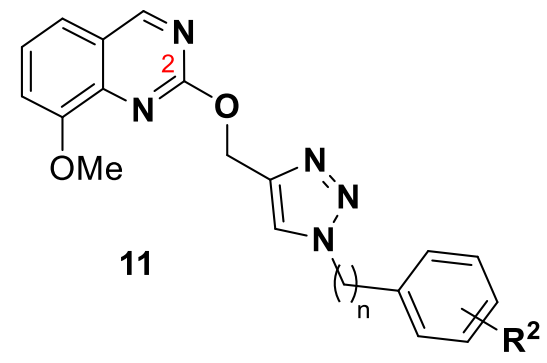

Figure 2. Our target molecules.

\section{Results and Discussion}

\section{Chemical synthesis}

Various strategies and disconnections have been reported for the synthesis of quinazolines. ${ }^{6-7}$ In our case we favored the approach through two C-N bond disconnections and starting from an ortho-aminobenzaldehyde derivative 13 (Scheme 1). Reaction with urea gave in good yield quinazoline 14 which was further treated by $\mathrm{POCl}_{3}$ to give chloroquinazoline 14a. This intermediate was reacted with propargyl alcohol to isolate in $65 \%$ yield propargyl ether 15 . Final click-type reactions, ${ }^{8-11}$ with various azido derivatives $16 a-j,{ }^{12}$ afforded the target molecules 11a-j in good yields (Table1).
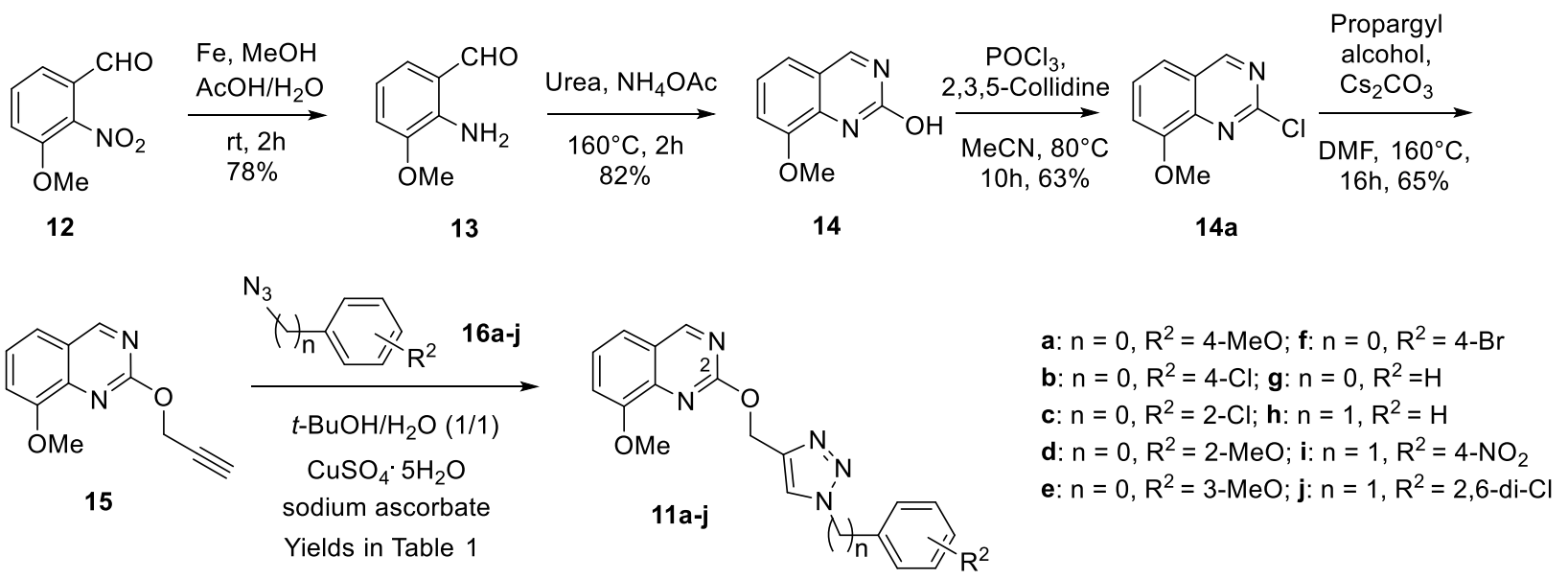

Scheme 1. Synthesis of quinazoline-based triazoles. 
Table 1. Synthesis of our target molecules

\begin{tabular}{ccccc}
\hline Entry & $\mathrm{n}$ & $\mathrm{R}^{2}$ & Molecule & Yield \% \\
\hline 1 & 0 & $4-\mathrm{MeO}$ & $\mathbf{1 1 a}$ & 75 \\
2 & 0 & $4-\mathrm{Cl}$ & $\mathbf{1 1 b}$ & 65 \\
3 & 0 & $2-\mathrm{Cl}$ & $\mathbf{1 1 c}$ & 64 \\
4 & 0 & $2-\mathrm{MeO}$ & $\mathbf{1 1 d}$ & 68 \\
5 & 0 & $3-\mathrm{MeO}$ & $\mathbf{1 1 e}$ & 71 \\
6 & 0 & $4-\mathrm{Br}$ & $\mathbf{1 1 f}$ & 64 \\
7 & 0 & $\mathrm{H}$ & $\mathbf{1 1 g}$ & 74 \\
8 & 1 & $\mathrm{H}$ & $\mathbf{1 1 h}$ & 74 \\
9 & 1 & $4-\mathrm{NO} 2$ & $\mathbf{1 1 i}$ & 50 \\
10 & 1 & $2,6-\mathrm{di}-\mathrm{Cl}$ & $\mathbf{1 1 j}$ & 60 \\
\hline
\end{tabular}

All intermediates and final products have spectral and analytical data in agreement with their structures.

\section{Biological studies}

Based on the known biological properties of molecules with quinazoline scaffolds, we performed a few primary biological screenings of the ten molecules 11a-11j.

First, their cytotoxicity has been checked on seven representative cancer cell lines (HuH7, CaCo-2, MDAMB231, HCT116, PC3, NCl-H727, MCF7). All compounds were found to be devoid of any significant cytotoxicity at $10 \mu \mathrm{M}$ concentration (See Supplementary Material).

Their activity was also screened against a panel of eight representative kinases (HsCDK5/p25, HsCDK9/CyclinT, HsPIM1, MmCLK1, RnDYRK1A, HsHASPIN, HsGSK3 $\beta, H s C K 1 \varepsilon)$ and the results are reported in Table 2. Interestingly only one of these kinases ( $M m C L K 1)$ was found to be responding to these derivatives. $A$ few molecules (11a, 11c, 11d, 11e, 11f, 11j) exhibited a moderate inhibition of this kinase at $10 \mu \mathrm{M}$. On the other hand, these molecules were found to be devoid of any significant activity at $10 \mu \mathrm{M}$ concentration on the other kinases. 
Table 2. Study of the inhibition of quinazolines $\mathbf{1 1}$ against a representative panel of mammalian kinases

\begin{tabular}{|c|c|c|c|c|c|c|c|c|c|}
\hline Compound & Concentration & $\begin{array}{c}\text { HsCDK5/ } \\
\text { p25 }\end{array}$ & $\begin{array}{c}\text { HsCDK9/ } \\
\text { Cyclint }\end{array}$ & HsPIM1 & MmCLK1 & RnDYRK1A & HsHASPIN & HsGSK3ß & HsCK1ع \\
\hline \multirow[t]{2}{*}{$11 a$} & $10 \mu \mathrm{M}$ & 104 & 87 & 95 & 63 & 104 & 99 & 87 & 108 \\
\hline & $1 \mu \mathrm{M}$ & 109 & 90 & 125 & 102 & 109 & 99 & 89 & 95 \\
\hline \multirow[t]{2}{*}{$11 b$} & $10 \mu \mathrm{M}$ & 118 & 89 & 125 & 105 & 98 & 97 & 86 & 121 \\
\hline & $1 \mu \mathrm{M}$ & 135 & 82 & 97 & 101 & 105 & 87 & 74 & 90 \\
\hline \multirow[t]{2}{*}{$11 \mathrm{c}$} & $10 \mu \mathrm{M}$ & 124 & 86 & 78 & 44 & 88 & 80 & 72 & 101 \\
\hline & $1 \mu \mathrm{M}$ & 110 & 79 & 94 & 102 & 107 & 105 & 87 & 99 \\
\hline \multirow[t]{2}{*}{$11 d$} & $10 \mu \mathrm{M}$ & 120 & 104 & 91 & 49 & 103 & 113 & 90 & 96 \\
\hline & $1 \mu \mathrm{M}$ & 106 & 92 & 100 & 98 & 98 & 109 & 86 & 97 \\
\hline \multirow[t]{2}{*}{$11 \mathrm{e}$} & $10 \mu \mathrm{M}$ & 101 & 103 & 99 & 26 & 98 & 111 & 78 & 87 \\
\hline & $1 \mu \mathrm{M}$ & 109 & 94 & 100 & 84 & 77 & 100 & 93 & 87 \\
\hline \multirow[t]{2}{*}{$11 f$} & $10 \mu \mathrm{M}$ & 79 & 110 & 98 & 48 & 117 & 114 & 105 & 105 \\
\hline & $1 \mu \mathrm{M}$ & 111 & 128 & 111 & 100 & 76 & 103 & 89 & 96 \\
\hline \multirow[t]{2}{*}{$11 \mathrm{~g}$} & $10 \mu \mathrm{M}$ & 113 & 101 & 105 & 106 & 110 & 112 & 100 & 97 \\
\hline & $1 \mu \mathrm{M}$ & 98 & 97 & 100 & 87 & 93 & 88 & 94 & 94 \\
\hline \multirow[t]{2}{*}{$11 \mathrm{~h}$} & $10 \mu \mathrm{M}$ & 112 & 112 & 106 & 74 & 100 & 116 & 103 & 116 \\
\hline & $1 \mu \mathrm{M}$ & 114 & 119 & 120 & 99 & 94 & 92 & 78 & 81 \\
\hline \multirow[t]{2}{*}{$11 i$} & $10 \mu \mathrm{M}$ & 116 & 128 & 121 & 109 & 144 & 118 & 110 & 113 \\
\hline & $1 \mu \mathrm{M}$ & 104 & 106 & 110 & 108 & 81 & 108 & 63 & 79 \\
\hline \multirow[t]{2}{*}{$11 \mathrm{j}$} & $10 \mu \mathrm{M}$ & 121 & 121 & 116 & 67 & 100 & 90 & 67 & 95 \\
\hline & $1 \mu \mathrm{M}$ & 113 & 85 & 127 & 129 & 84 & 98 & 55 & 61 \\
\hline
\end{tabular}

Percentages of residual kinase activity were determined at 1 and $10 \mu \mathrm{M}$ concentration for each compound. Kinase activities were assayed in duplicate.

\section{Conclusions}

In summary, we designed a short and convergent strategy toward the desired quinazolines linked to triazoles through an ether chain in position 2 of the quinazoline. Some of these derivatives exhibit a moderate, but significant and selective, activity against the MmCLK1 kinase. Extension of this approach to other quinazolinederived derivatives is under active study and will be reported in due course.

\section{Experimental Section}

\section{Chemical Synthesis}

General. All anhydrous reactions were performed in heat gun-dried round-bottomed flasks under a dry argon or nitrogen atmosphere. Air and moisture-sensitive compounds were introduced via syringes or cannula, using 
standard inert atmosphere techniques. In addition, the gas stream was passed through glass cylinder filled with $\mathrm{P}_{2} \mathrm{O}_{5}$ to remove any traces of residual moisture. Reactions were monitored by thin layer chromatography (TLC) using E. Merck silica gel plates and components were visualized by illumination with short wavelength UV light and/or staining (Ninhydrin or basic $\mathrm{KMnO}_{4}$ ). THF and $\mathrm{Et}_{2} \mathrm{O}$ were dried over sodium-benzophenone and distilled prior to use. Anhydrous $\mathrm{CH}_{2} \mathrm{Cl}_{2}$ was prepared by refluxing in the presence of $\mathrm{CaH}_{2}$ and distilled right before use unless otherwise noted. Infrared spectra have been recorded on a Bruker alpha II FTIR spectrometer. ${ }^{1} \mathrm{H}$ NMR spectra were recorded at 300 and $400 \mathrm{MHz}$, and ${ }^{13} \mathrm{C} \mathrm{NMR}$ spectra at 75 and $100 \mathrm{MHz}$,in $\mathrm{CDCl}_{3}$ or DMSO- $d_{6}$ using tetramethylsilane (TMS) as an internal standard on Bruker spectrometers (Avance $300 I I I$ and Avance 300I and Avance III 400). Assignments were made using standard 2D NMR techniques (COSY, $\mathrm{HMQC} / \mathrm{HSQC}, \mathrm{HMBC}$ ). High resolution mass spectra were performed using a time of flight Maxis $4 \mathrm{G}$ (Bruker Daltonik Gmbh, Bremen, Germany) in Electrospray positive ionization mode. LC-MS analyses were carried out on a Shimadzu [LCMS-2020], SHIMPAK, XR ODS-II column $(50 \times 2 \mathrm{~mm})$ utilizing the following method. Solvent A $=$ Acetonitrile, $B=0.1 \%$ TFA in water; Initial $95 \%$ of solvent $B$, then run gradient, which should reach $90 \%$ solvent $A$ within $10 \mathrm{~min}$ and hold $90 \%$ solvent $A$ for another $10 \mathrm{~min}$. Flow Rate: $0.2 \mathrm{ml} / \mathrm{min}$.

Synthesis of 2-amino-3-methoxybenzaldehyde (13). To a stirred solution of 3-methoxy-2-nitrobenzaldehyde (12) $(10 \mathrm{~g}, 54 \mathrm{mmol})$ in a mixture of methanol $(100 \mathrm{~mL})$ and glacial acetic acid $(100 \mathrm{~mL})$ and water $(50 \mathrm{~mL}) \mathrm{was}$ added reduced iron powder $(16 \mathrm{~g}, 144 \mathrm{mmol})$ in lot wise manner. The resulting suspension was stirred at 30$35^{\circ} \mathrm{C}$ for $2 \mathrm{~h}$. The reaction mixture was filtered on Celite bed and washed with methanol (50 $\left.\mathrm{mL}\right)$. The filtrate was concentrated to remove volatiles and it was partitioned between sat. $\mathrm{NaHCO}_{3}(150 \mathrm{~mL})$ and ethyl acetate $(200 \mathrm{~mL})$. The basic layer was further extracted with ethyl acetate $(100 \mathrm{~mL})$. The combined organic extracts were washed with brine $(50 \mathrm{~mL})$, dried over $\mathrm{Na}_{2} \mathrm{SO}_{4}$ and concentrated to dryness and purified by chromatography on silica gel eluting with 20\% EtOAc in hexane giving a compound 13 (6.5 g, 78\% Yield) as a off white solid. ${ }^{1} \mathrm{H}$ NMR (400 MHz, $\left.\mathrm{CDCl}_{3}\right) \delta$ ppm: $9.93(\mathrm{~s}, 1 \mathrm{H}), 8.45(\mathrm{~d}, 1 \mathrm{H}), 7.82(\mathrm{~d}, 1 \mathrm{H}), 6.80(\mathrm{t}, 1 \mathrm{H})$; Mass $(\mathrm{m} / \mathrm{z}): 165.2(\mathrm{M}+\mathrm{H})$.

Synthesis of 8-methoxyquinazolin-2-ol (14). 2-Amino-3-methoxybenzaldehyde (13) (5 g, $33.1 \mathrm{mmol}$ ), urea (20 $\mathrm{g}, 336.3 \mathrm{mmol}$ ) and cat. $\mathrm{NH}_{4} \mathrm{OAc}(10 \mathrm{mg})$ were thoroughly mixed together in a round bottom flask. The solid mixture was heated to $160{ }^{\circ} \mathrm{C}$ and the solids quickly melted and stirring was continued for $15 \mathrm{~min}$. A solid started to precipitate from the hot solution, NMP $(25 \mathrm{~mL})$ was added to dissolve the solids, the reaction was heated with stirring for an additional $2 \mathrm{~h}$ at $155-160^{\circ} \mathrm{C}$. The hot reaction mixture was poured into vigorously stirred ice water $(150 \mathrm{~mL})$. The reaction mixture was filtered, washed with water $(50 \mathrm{~mL})$ and ethyl acetate (15 $\mathrm{mL}$ ) giving a brown color solid which was dried to give compound 14 (4.9 g, 82\% yield) as a off white solid. ${ }^{1} \mathrm{H}$

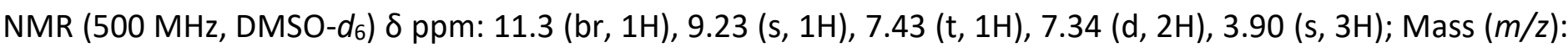
$177.2(\mathrm{M}+\mathrm{H})$

Synthesis of 2-chloro-8-methoxyquinazoline (14a). A mixture of compound 14 (4 g, $22 \mathrm{mmol}$ ) and 2,3,5collidine $(5 \mathrm{~mL}, 38.8 \mathrm{mmol})$ in acetonitrile $(80 \mathrm{~mL})$ was stirred at room temperature for $10 \mathrm{~min}$. $\mathrm{POCl}_{3}(22 \mathrm{~mL}$, $222 \mathrm{mmol}$ ) was added to reaction mixture at $0{ }^{\circ} \mathrm{C}$ and the reaction mixture was heated for $10 \mathrm{~h}$ at reflux. The mixture was concentrated to dryness. The obtained residue was partitioned between EtOAc $(200 \mathrm{~mL})$ and sat. $\mathrm{NaHCO}_{3}(200 \mathrm{~mL})$. The mixture was stirred cautiously watching gas evolution until the $\mathrm{pH}$ reached to 8 . The layers were separated and the organic layer was washed with sat. $\mathrm{NaHCO}_{3}(75 \mathrm{ml})$, brine $(50 \mathrm{ml})$, dried $\left(\mathrm{Na}_{2} \mathrm{SO}_{4}\right)$, and concentrated to dryness, giving compound $14 \mathrm{a}\left(2.8 \mathrm{~g}, 63.5 \%\right.$ yield) as a pale yellow solid. ${ }^{1} \mathrm{H}$

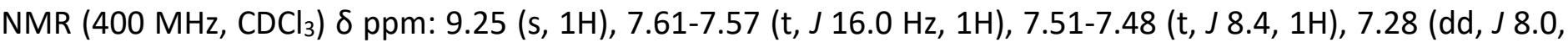
$0.8 \mathrm{~Hz}, 1 \mathrm{H}), 4.07(\mathrm{~s}, 3 \mathrm{H}) ;{ }^{13} \mathrm{C} \mathrm{NMR}\left(400 \mathrm{MHz}, \mathrm{CDCl}_{3}\right): \delta 162.72,156.93,154.08,143.80,128.59,124.33,118.41$, 113.08, 56.26. Mass $(\mathrm{m} / \mathrm{z}): 195.1(\mathrm{M}+\mathrm{H})$. 
Synthesis of 8-methoxy-2-(prop-2-yn-1-yloxy)quinazoline (15). Propargyl alcohol (518 mg, $9.24 \mathrm{mmol})$ was added to a stirred suspension of $\mathrm{Cs}_{2} \mathrm{CO}_{3}(3 \mathrm{~g}, 9.24 \mathrm{mmol})$ and $\mathrm{DMF}(10 \mathrm{~mL})$, after stirring 15 minutes at $30{ }^{\circ} \mathrm{C}$ compound 14a (600 mg, $3.08 \mathrm{mmol}$ ) was added. After stirring at $100{ }^{\circ} \mathrm{C}$ for $16 \mathrm{~h}$, the reaction mixture was quenched with water $(30 \mathrm{~mL})$ and extracted with DCM $(2 \times 25 \mathrm{~mL})$. The combined organic extracts were washed with brine $(5 \%, 15 \mathrm{~mL})$, dried over $\mathrm{Na}_{2} \mathrm{SO}_{4}$ and concentrated to dryness. Purification by chromatography on silica gel (elution with EtOAc in hexane) gave compound 15 (450 mg, 65\% yield) as a off white solid. ${ }^{1} \mathrm{H}$ NMR $\left(400 \mathrm{MHz}_{\mathrm{CDCl}}\right.$ ) $\delta$ ppm: $9.23(\mathrm{~s}, 1 \mathrm{H}), 7.46-7.38(\mathrm{~m}, 2 \mathrm{H}), 7.21(\mathrm{~d}, J 7.6,1.6 \mathrm{~Hz}, 1 \mathrm{H}), 5.21(\mathrm{~s}, 2 \mathrm{H}), 4.06(\mathrm{~s}, 3 \mathrm{H})$, 2.49 (t, J $2.4 \mathrm{~Hz}, 1 \mathrm{H}) ;{ }^{13} \mathrm{C} \mathrm{NMR}\left(400 \mathrm{MHz}, \mathrm{CDCl}_{3}\right): \delta$ 163.62, 161.11, 153.84, 143.67, 125.43, 122.96, 118.90, $113.06,78.55,74.63,56.33,55.18$. Mass $(m / z): 215.1(\mathrm{M}+\mathrm{H})$.

General procedure for preparation of compounds, 11a-j. To the stirred solution of compound 15 (0.1 mmol, 1.0 eq.) and compound $\mathbf{1 6 a - j}$ [prepared using general protocol, ${ }^{12}(0.1 \mathrm{mmol}, 1$ eq. $)$ in a 1:1 mixture of $t$-butanol and water $(0.56 \mathrm{~mL})$ was added copper sulfate pentahydrate $(0.01 \mathrm{mmol}, 0.1 \mathrm{eq}$.$) and sodium ascorbate (0.03$ $\mathrm{mmol}, 0.3$ eq.) at room temperature. The resulting mixture was stirred for overnight. After completion of the reaction, it was diluted with a mixture of ethyl acetate and water $(7.5 \mathrm{ml}$ in a 1:1 ratio), the organic layer was separated and washed with $5 \%$ ammonium hydroxide solution $(0.5 \mathrm{~mL})$ and followed by brine $(0.5 \mathrm{~mL})$. The combined organic layers were dried over $\mathrm{Na}_{2} \mathrm{SO}_{4}$. The solvents were evaporated under reduced pressure to get the crude product, which was purified by chromatography on silica gel affording target compounds 11a-j (65-75\% yield) as light yellow to brown solids.

8-Methoxy-2-((1-(4-methoxyphenyl)-1H-1,2,3-triazol-4-yl)methoxy)quinazoline (11a). Reaction of 15 (25 mg, $0.11 \mathrm{mmol})$ with $16 \mathrm{a}(17.4 \mathrm{mg}, 0.11 \mathrm{mmol})$ gave $11 \mathrm{a}: 31.6 \mathrm{mg}, 75 \%$ yield. $\mathrm{mp} 179-181{ }^{\circ} \mathrm{C}$; $\mathrm{FT}-\mathrm{IR}\left(\mathrm{KBr}, \mathrm{cm}^{-1}\right)$ : $3137,2958,2841,1584,1516,1470,1419,1292,1261,1175,1117,1034,836,763 .{ }^{1} \mathrm{H} \mathrm{NMR}\left(300 \mathrm{MHz} \mathrm{CDCl}_{3}\right)$ : $\delta 9.23$ (s, $1 \mathrm{H}, \mathrm{H}$-quinazoline), 8.37 (br t, $J 0.5 \mathrm{~Hz}, 1 \mathrm{H}, \mathrm{H}$-triazole), 7.62 (half part of an $\mathrm{A}_{2} \mathrm{X}_{2}$ system, $2 \mathrm{H}$ meta to OMe), 7.46 (dd, J 8.1, 1.6 Hz, 1H, H-C7 of quinazoline), 7.40 (dd, J 8.1, $7.4 \mathrm{~Hz}, 1 \mathrm{H}, \mathrm{H}$-C6 of quinazoline), 7.22 (ddd, J 7.4, 1.6, $0.2 \mathrm{~Hz}, 1 \mathrm{H}, \mathrm{H}-\mathrm{C} 5$ of quinazoline), 7.01 (half part of an $\mathrm{A}_{2} \mathrm{X}_{2}$ system, $2 \mathrm{H}$ ortho to $\mathrm{OMe}$ ), 5.80 (d, J $0.5 \mathrm{~Hz}, 2 \mathrm{H}, \mathrm{CH}_{2}$ ), 4.09 (s, 3H, $\mathrm{CH}_{3}, \mathrm{OMe}$ on quinazoline), 3.86 (s, 3H, $\mathrm{CH}_{3}, \mathrm{OMe}$ of 4-methoxyphenyl). ${ }^{13} \mathrm{C} \mathrm{NMR}$ (75 MHz, $\left.\mathrm{CDCl}_{3}\right): \delta 163.72(\mathrm{CH}, \alpha$ to $\mathrm{N}$ of quinazoline), $161.65(C, C 2$ of quinazoline), 159.81 (C, $\alpha$ to OMe), 153.83 ( $C, C 8$ of quinazoline), 144.19 ( $C$ of triazole), 143.59 ( $C, C 8$ a of quinazoline), 130.67 ( $C, \delta$ to OMe), $125.28(\mathrm{CH}, \mathrm{C6}$ of quinazoline), 122.92 ( $\mathrm{CH}$ of triazole), 122.89 ( $\mathrm{C}, \mathrm{C} 4 \mathrm{a}$ of quinazoline), 122.15 (2CH, meta to OMe), $118.99\left(\mathrm{CH}, \mathrm{C7}\right.$ of quinazoline), $114.78\left(2 \mathrm{CH}\right.$, ortho to OMe), $112.87\left(\mathrm{CH}, \mathrm{C5}\right.$ of quinazoline), $61.33\left(\mathrm{CH}_{2}\right)$, $56.23\left(\mathrm{CH}_{3}, \mathrm{OMe}\right.$ on quinazoline), $55.64\left(\mathrm{CH}_{3}, \mathrm{OMe}\right.$ of 4-methoxyphenyl). LC-MS: 363.13 [M]. HRMS-ESI (m/z) $[\mathrm{M}+\mathrm{Na}]^{+}$calcd for $\mathrm{C}_{19} \mathrm{H}_{17} \mathrm{~N}_{5} \mathrm{NaO}_{3}: 386.12236$, found 386.1222, [M+K] $]^{+}$calcd for $\mathrm{C}_{19} \mathrm{H}_{17} \mathrm{KN}_{5} \mathrm{O}_{3}: 402.09630$, found 402.0957.

2-((1-(4-Chlorophenyl)-1H-1,2,3-triazol-4-yl)methoxy)-8-methoxyquinazoline (11b). Reaction of 15 (25 mg, $0.11 \mathrm{mmol}$ ) with 16b (17.92 mg, $0.11 \mathrm{mmol})$ gave $11 \mathrm{~b}: 28 \mathrm{mg}, 65 \%$ yield. $\mathrm{mp} 130{ }^{\circ} \mathrm{C}(\mathrm{dec}) ; \mathrm{FT}-\mathrm{IR}\left(\mathrm{KBr}, \mathrm{cm}^{-1}\right)$ : $3339,3332,2999,1581,1493,1421,1382,1293,1171,1108,1029,830,756 .{ }^{1} \mathrm{H} \mathrm{NMR}\left(400 \mathrm{MHz} \mathrm{CDCl}_{3}\right): \delta$ $9.24\left(\mathrm{~s}, 1 \mathrm{H}, \mathrm{H}\right.$-quinazoline), 8.47 (s, $1 \mathrm{H}, \mathrm{H}$-triazole), 7.68 (half part of an $\mathrm{A}_{2} \mathrm{X}_{2}$ system, $2 \mathrm{H}$ meta to $\mathrm{Cl}$ ), 7.49 (half part of an $\mathrm{A}_{2} \mathrm{X}_{2}$ system, $2 \mathrm{H}$ ortho to $\mathrm{Cl}$ ), $7.46(\mathrm{dd}, J 8.2,1.4 \mathrm{~Hz}, 1 \mathrm{H}, \mathrm{H}$-C7 of quinazoline), 7.42 (dd, J 8.2, $7.5 \mathrm{~Hz}$, $1 \mathrm{H}, \mathrm{H}$-C6 of quinazoline), 7.23 (dd, $J 7.6,1.4 \mathrm{~Hz}, 1 \mathrm{H}, \mathrm{H}-\mathrm{C} 5$ of quinazoline), $5.80\left(\mathrm{~d}, J 0.6 \mathrm{~Hz}, 2 \mathrm{H}, \mathrm{CH}_{2}\right), 4.10(\mathrm{~s}$, $\left.\left.3 \mathrm{H}, \mathrm{CH}_{3}, \mathrm{OMe}\right),{ }^{13} \mathrm{C} \mathrm{NMR} \mathrm{(100} \mathrm{MHz}, \mathrm{CDCl}_{3}\right): \delta 163.77(\mathrm{CH}, \alpha$ to $\mathrm{N}$ of quinazoline), $161.58(\mathrm{C}, \mathrm{C2}$ of quinazoline), 153.80 ( $C, C 8$ of quinazoline), 144.68 ( $C$ of triazole), 143.53 (C, C8a of quinazoline), $135.66(C, \delta$ to $C l), 134.50$ (C, $\alpha$ to $\mathrm{Cl}), 129.94(2 \mathrm{CH}$, ortho to $\mathrm{Cl}), 125.36(\mathrm{CH}, \mathrm{C6}$ of quinazoline), 122.91 (C, C4a of quinazoline), 122.77 ( $\mathrm{CH}$ of triazole), $121.65(2 \mathrm{CH}$, meta to $\mathrm{Cl}), 119.04(\mathrm{CH}, \mathrm{C7}$ of quinazoline), $112.93(\mathrm{CH}, \mathrm{C5}$ of quinazoline $), 61.17$ 
$\left(\mathrm{CH}_{2}\right), 56.23\left(\mathrm{CH}_{3}, \mathrm{OMe}\right)$. LC-MS: 367.79 [M]. HRMS-ESI $(\mathrm{m} / z)[\mathrm{M}+\mathrm{Na}]^{+}$calcd for $\mathrm{C}_{18} \mathrm{H}_{14}{ }^{35} \mathrm{ClN}_{5} \mathrm{NaO}_{2}: 390.07282$, found 390.0726, $[\mathrm{M}+\mathrm{K}]^{+}$calcd for $\mathrm{C}_{18} \mathrm{H}_{14}{ }^{35} \mathrm{CIKN}_{5} \mathrm{O}_{2}$ : 406.04676, found 406.0460 .

2-((1-(2-Chlorophenyl)-1H-1,2,3-triazol-4-yl)methoxy)-8-methoxyquinazoline (11c). Reaction of 15 (20 mg, $0.093 \mathrm{mmol})$ with $16 \mathrm{c}(14.28 \mathrm{mg}, 0.11 \mathrm{mmol})$ gave $11 \mathrm{c}: 22.1 \mathrm{mg}, 64 \%$ yield. $\mathrm{mp} 134-136{ }^{\circ} \mathrm{C} ; \mathrm{FT}-\mathrm{IR}\left(\mathrm{KBr}, \mathrm{cm}^{-1}\right)$ : $3146,3004,1580,1486,1417,1382,1288,1168,1119,1022,757,665 .{ }^{1} \mathrm{H} \mathrm{NMR}\left(300 \mathrm{MHz}, \mathrm{CDCl}_{3}\right): \delta 9.23(\mathrm{~s}$, 1H, $H$-quinazoline), 8.48 (br t, J $0.5 \mathrm{~Hz}, 1 \mathrm{H}, \mathrm{H}$-triazole), 7.66-7.59 (m, $1 \mathrm{H}, \mathrm{H}$-4 of 2-chlorophenyl), 7.59-7.53 (m, $1 \mathrm{H}, \mathrm{H}$-5 of 2-chlorophenyl), 7.48-7.40 (m, 3H, $\mathrm{H}-3$ and $\mathrm{H}-6$ of 2-chlorophenyl and $\mathrm{H}$-C7 of quinazoline), 7.40 (dd, J 8.1, 7.4 Hz, 1H, H-C6 of quinazoline), 7.20 (dd, J 7.4, $1.6 \mathrm{~Hz}, 1 \mathrm{H}, \mathrm{H}$-C5 of quinazoline), $5.84(\mathrm{~d}, J 0.5 \mathrm{~Hz}$, $\left.2 \mathrm{H}, \mathrm{CH}_{2}\right), 4.06\left(\mathrm{~s}, 3 \mathrm{H}, \mathrm{CH}_{3}, \mathrm{OMe}\right) .{ }^{13} \mathrm{C} \mathrm{NMR}\left(75 \mathrm{MHz}, \mathrm{CDCl}_{3}\right): \delta 163.74(\mathrm{CH}, \alpha$ to $\mathrm{N}$ of quinazoline), $161.54(\mathrm{C}, \mathrm{C2}$ of quinazoline), 153.73 ( $C, C 8$ of quinazoline), 143.42 ( $C, C 8$ a of quinazoline), 143.32 ( $C$ of triazole), 134.93 (C) $\alpha$ to $\mathrm{Cl}), 130.75(\mathrm{CH}, \mathrm{C5}$ of 2-chlorophenyl), $130.62(\mathrm{CH}, \mathrm{C6}$ of 2-chlorophenyl), $128.29(\mathrm{C}, \mathrm{C1}$ of 2chlorophenyl), $127.94(\mathrm{CH}, \mathrm{C3}$ of 2-chlorophenyl), $127.76(\mathrm{CH}, \mathrm{C4}$ of 2-chlorophenyl), $126.89(\mathrm{CH}$ of triazole), $125.29(\mathrm{CH}, \mathrm{C} 6$ of quinazoline), $122.80(\mathrm{C}, \mathrm{C4}$ a of quinazoline), $118.90(\mathrm{CH}, \mathrm{C7}$ of quinazoline), $112.70(\mathrm{CH}, \mathrm{C5}$ of quinazoline), $61.03\left(\mathrm{CH}_{2}\right), 56.13\left(\mathrm{CH}_{3}, \mathrm{OMe}\right)$. LC-MS: 367.79 [M]. HRMS-ESI $(\mathrm{m} / \mathrm{z})[\mathrm{M}+\mathrm{Na}]^{+}$calcd for $\mathrm{C}_{18} \mathrm{H}_{14}{ }^{35} \mathrm{CIN}_{5} \mathrm{NaO}_{2}$ : 390.07282, found 390.0729, [M+K] ${ }^{+}$calcd for $\mathrm{C}_{18} \mathrm{H}_{14}{ }^{35} \mathrm{ClKN}_{5} \mathrm{O}_{2}: 406.04676$, found 406.0462, $[\mathrm{M}+\mathrm{H}]^{+}$calcd for $\mathrm{C}_{18} \mathrm{H}_{15}{ }^{35} \mathrm{ClN}_{5} \mathrm{O}_{2}: 368.09088$, found 368.0904 .

8-Methoxy-2-((1-(2-methoxyphenyl)-1H-1,2,3-triazol-4-yl)methoxy)quinazoline (11d). Reaction of 15 (25 mg, $0.11 \mathrm{mmol})$ with $16 \mathrm{~d}(17.4 \mathrm{mg}, 0.11 \mathrm{mmol})$ gave $11 \mathrm{~d}: 29.4 \mathrm{mg}, 68 \%$ yield. $\mathrm{mp} 147-149{ }^{\circ} \mathrm{C}$; $\mathrm{FT}-\mathrm{IR}\left(\mathrm{KBr}, \mathrm{cm}^{-1}\right)$ : $3157,2963,2838,1580,1470,1417,1286,1170,1119,1017,753,668 .{ }^{1} \mathrm{H} \mathrm{NMR}\left(300 \mathrm{MHz}, \mathrm{CDCl}_{3}\right): \delta 9.23(\mathrm{~s}$, $1 \mathrm{H}, \mathrm{H}$-quinazoline), $8.44(\mathrm{br} \mathrm{t}, J 0.6 \mathrm{~Hz}, 1 \mathrm{H}, \mathrm{H}$-triazole), 7.77 (ddd, J 7.8, 1.7, $0.3 \mathrm{~Hz}, 1 \mathrm{H}, \mathrm{H6}$ of 2 methoxyphenyl), 7.45 (dd, J 8.2, $1.5 \mathrm{~Hz}, 1 \mathrm{H}, \mathrm{H}$-C7 of quinazoline), 7.41 (ddd, J 8.2, 7.6, $1.7 \mathrm{~Hz}, 1 \mathrm{H}, \mathrm{H}$-C6 of quinazoline), 7.39 (dd, J 8.1, $7.4 \mathrm{~Hz}, 1 \mathrm{H}, \mathrm{H} 4$ of 2-methoxyphenyl), 7.20 (br dd, J 7.5, $1.5 \mathrm{~Hz}, 1 \mathrm{H}, \mathrm{H}-\mathrm{C} 5 \mathrm{of}$ quinazoline), 7.09 (td, J 7.7, $1.3 \mathrm{~Hz}, 1 \mathrm{H}, \mathrm{H} 5$ of 2-methoxyphenyl), 7.07 (br dd, J 8.3, $1.1 \mathrm{~Hz}, 1 \mathrm{H}, \mathrm{H3}$ of 2methoxyphenyl), $5.84\left(\mathrm{~d}, \mathrm{~J} 0.6 \mathrm{~Hz}, 2 \mathrm{H}, \mathrm{CH}_{2}\right), 4.07$ (s, 3H, $\mathrm{CH}_{3}, \mathrm{OMe}$ on quinazoline), $3.84\left(\mathrm{~s}, 3 \mathrm{H}, \mathrm{CH}_{3}, \mathrm{OMe}\right.$ of 2methoxyphenyl). $\left.{ }^{13} \mathrm{C} \mathrm{NMR} \mathrm{(75} \mathrm{MHz,} \mathrm{CDCl}_{3}\right): \delta 163.63(\mathrm{CH}, \alpha$ to $\mathrm{N}$ of quinazoline), $161.70(\mathrm{C}, \mathrm{C2}$ of quinazoline), 153.85 ( $C, C 8$ of quinazoline), 151.23 ( $C \alpha$ to OMe of 2-methoxyphenyl), 143.69 ( $C, C 8$ a of quinazoline), 143.03 ( $\mathrm{C}$ of triazole), 130.04 ( $\mathrm{CH}, \mathrm{C4}$ of 2-methoxyphenyl), 126.47 ( $\mathrm{CH}$ of triazole), 126.41 (C, $\mathrm{C} 1$ of 2-methoxyphenyl), $125.62(\mathrm{CH}, \mathrm{C} 6$ of 2-methoxyphenyl), $125.20(\mathrm{CH}, \mathrm{C} 6$ of quinazoline), 122.85 (C, C4a of quinazoline), 121.22 $(\mathrm{CH}, \mathrm{C5}$ of 2-methoxyphenyl), $118.94(\mathrm{CH}, \mathrm{C7}$ of quinazoline), $112.83(\mathrm{CH}, \mathrm{C5}$ of quinazoline), $112.27(\mathrm{CH}, \mathrm{C3}$ of 2-methoxyphenyl), $61.38\left(\mathrm{CH}_{2}\right), 56.23\left(\mathrm{CH}_{3}, \mathrm{OMe}\right.$ on quinazoline), $55.94\left(\mathrm{CH}_{3}, \mathrm{OMe}\right.$ of 2-methoxyphenyl). LCMS: 363.13 [M]. HRMS-ESI $(\mathrm{m} / \mathrm{z})[\mathrm{M}+\mathrm{Na}]^{+}$calcd for $\mathrm{C}_{19} \mathrm{H}_{17} \mathrm{~N}_{5} \mathrm{NaO}_{3}: 386.12236$, found 386.1228, $[\mathrm{M}+\mathrm{K}]^{+}$calcd for $\mathrm{C}_{19} \mathrm{H}_{17} \mathrm{KN}_{5} \mathrm{O}_{3}: 402.09630$, found 402.0963, [M+H] ${ }^{+}$calcd for $\mathrm{C}_{19} \mathrm{H}_{18} \mathrm{~N}_{5} \mathrm{O}_{3}$ : 364.14041, found 364.1404.

8-Methoxy-2-((1-(3-methoxyphenyl)-1H-1,2,3-triazol-4-yl)methoxy)quinazoline (11e). Reaction of 15 (25 mg, $0.11 \mathrm{mmol}$ ) with 16e (17.4 mg, $0.11 \mathrm{mmol})$ gave $11 \mathrm{e}: 30 \mathrm{mg}, 71 \%$ yield. $\mathrm{mp} 137-139{ }^{\circ} \mathrm{C}$; FT-IR $\left(\mathrm{KBr}, \mathrm{cm}^{-1}\right): 3144$, $3002,1594,1483,1420,1289,1165,1015,1031,855,764 .{ }^{1} \mathrm{H} \mathrm{NMR}\left(300 \mathrm{MHz}, \mathrm{CDCl}_{3}\right): \delta 9.23(\mathrm{~s}, 1 \mathrm{H}, \mathrm{H}-$ quinazoline), 8.48 (br t, J $0.6 \mathrm{~Hz}, 1 \mathrm{H}, \mathrm{H}$-triazole), 7.46 (dd, J 8.2, $1.6 \mathrm{~Hz}, 1 \mathrm{H}, \mathrm{H}$-C7 of quinazoline), 7.44-7.36 (m, $2 \mathrm{H}, \mathrm{H}$-C6 of quinazoline at $7.43 \mathrm{ppm}$ and $\mathrm{H} 5$ of 3-methoxyphenyl at $7.39 \mathrm{ppm}), 7.34(\mathrm{dd}, J 2.4,2.1 \mathrm{~Hz}, 1 \mathrm{H}, \mathrm{H} 2 \mathrm{of}$ 3-methoxyphenyl), 7.26 (ddd, J 8.0, 2.1, $1.0 \mathrm{~Hz}, 1 \mathrm{H}, \mathrm{H6}$ of 3-methoxyphenyl), 7.23 (br dd, J 7.5, 1.6 Hz, $1 \mathrm{H}, \mathrm{H}-\mathrm{C} 5$ of quinazoline), 6.96 (ddd, J 8.3, 2.5, $1.0 \mathrm{~Hz}, 1 \mathrm{H}, \mathrm{H} 4$ of 3-methoxyphenyl), 5.81 (d, J $\left.0.5 \mathrm{~Hz}, 2 \mathrm{H}, \mathrm{CH}_{2}\right), 4.10(\mathrm{~s}$, $3 \mathrm{H}, \mathrm{CH}_{3}, \mathrm{OMe}$ on quinazoline), $3.87\left(\mathrm{~s}, 3 \mathrm{H}, \mathrm{CH}_{3}\right.$, OMe of 3-methoxyphenyl). $\left.{ }^{13} \mathrm{C} \mathrm{NMR} \mathrm{(75} \mathrm{MHz,} \mathrm{CDCl}_{3}\right): \delta 163.74$ $(\mathrm{CH}, \alpha$ to $\mathrm{N}$ of quinazoline), 161.63 (C, $\mathrm{C2}$ of quinazoline), 160.64 (C, $\alpha$ to OMe of 3-methoxyphenyl), 153.83 (C, C8 of quinazoline), 144.34 ( $C$ of triazole), 143.56 (C, C8a of quinazoline), 138.20 ( $C, C 1$ of 3-methoxyphenyl), $130.49(\mathrm{CH}, \mathrm{C5}$ of 3-methoxyphenyl), $125.30(\mathrm{CH}, \mathrm{C6}$ of quinazoline), 122.96 ( $\mathrm{CH}$ of triazole), 122.90 ( $\mathrm{C}, \mathrm{C4a}$ of quinazoline), $119.00(\mathrm{CH}, \mathrm{C7}$ of quinazoline), $114.60(\mathrm{CH}, \mathrm{C4}$ of 3-methoxyphenyl), $112.88(\mathrm{CH}, \mathrm{C5}$ of 
quinazoline), $112.33\left(\mathrm{CH}, \mathrm{C} 6\right.$ of 3-methoxyphenyl), $106.31\left(\mathrm{CH}, \mathrm{C2}\right.$ of 3-methoxyphenyl), $61.27\left(\mathrm{CH}_{2}\right), 56.24$ $\left(\mathrm{CH}_{3}\right.$, OMe on quinazoline), $55.64\left(\mathrm{CH}_{3}\right.$, OMe of 3-methoxyphenyl). LC-MS: 363.13 [M]. HRMS-ESI (m/z) $[\mathrm{M}+\mathrm{Na}]^{+}$calcd for $\mathrm{C}_{19} \mathrm{H}_{17} \mathrm{~N}_{5} \mathrm{NaO}_{3}: 386.12236$, found 386.1277, $[\mathrm{M}+\mathrm{K}]^{+}$calcd for $\mathrm{C}_{19} \mathrm{H}_{17} \mathrm{KN}_{5} \mathrm{O}_{3}: 402.09630$, found 402.0962 .

2-((1-(4-Bromophenyl)-1H-1,2,3-triazol-4-yl)methoxy)-8-methoxyquinazoline (11f):. Reaction of 15 (25 mg, $0.11 \mathrm{mmol})$ with $16 \mathrm{f}(23.1 \mathrm{mg}, 0.11 \mathrm{mmol})$ gave $11 \mathrm{f}: 31 \mathrm{mg}, 64 \%$ yield. $\mathrm{mp} 144-146{ }^{\circ} \mathrm{C}$; $\mathrm{FT}-\mathrm{IR}\left(\mathrm{KBr}, \mathrm{cm}^{-1}\right): 3061$, 3007, 1581, 1491, 1418, 1291, 1172, 1024, 829, 762. ${ }^{1} \mathrm{H} \mathrm{NMR}\left(400 \mathrm{MHz}, \mathrm{CDCl}_{3}\right.$ ): $\delta 9.24$ (s, 1H, $\mathrm{H}$-quinazoline), 8.47 (br t, J $0.6 \mathrm{~Hz}, 1 \mathrm{H}, \mathrm{H}$-triazole), 7.67-7.60 (symmetrical m, $4 \mathrm{H}$ of 4-bromophenyl), 7.47 (dd, $J 8.1,1.4 \mathrm{~Hz}, 1 \mathrm{H}$, $\mathrm{H}-\mathrm{C} 7$ of quinazoline), 7.42 (dd, J 8.1, $7.5 \mathrm{~Hz}, 1 \mathrm{H}, \mathrm{H}-\mathrm{C} 6$ of quinazoline), 7.23 (dd, J 7.6, $1.3 \mathrm{~Hz}, 1 \mathrm{H}, \mathrm{H}-\mathrm{C} 5 \mathrm{of}$ quinazoline), 5.80 (br d, J $\left.0.6 \mathrm{~Hz}, 2 \mathrm{H}, \mathrm{CH}_{2}\right), 4.10\left(\mathrm{~s}, 3 \mathrm{H}, \mathrm{CH}_{3}, \mathrm{OMe}\right) .{ }^{13} \mathrm{C} \mathrm{NMR}\left(100 \mathrm{MHz}, \mathrm{CDCl}_{3}\right): \delta 163.78(\mathrm{CH}, \alpha$ to $\mathrm{N}$ of quinazoline), 161.57 ( $C, C 2$ of quinazoline), 153.79 ( $C, C 8$ of quinazoline), 144.70 ( $C$ of triazole), 143.51 (C, C8a of quinazoline), $136.13(\mathrm{C}, \delta$ to $\mathrm{Br}), 132.91(2 \mathrm{CH}$, ortho to $\mathrm{Br}$ of 4-bromophenyl), $125.36(\mathrm{CH}, \mathrm{C6}$ of quinazoline), 122.91 ( $C, C 4 a$ of quinazoline), 122.73 ( $\mathrm{CH}$ of triazole), $122.34(\mathrm{C}, \alpha$ to $\mathrm{Br}), 121.88(2 \mathrm{CH}$, meta to $\mathrm{Br}$ of 4-bromophenyl), $119.07\left(\mathrm{CH}, \mathrm{C7}\right.$ of quinazoline), $112.92\left(\mathrm{CH}, \mathrm{C5}\right.$ of quinazoline), $61.17\left(\mathrm{CH}_{2}\right), 56.23\left(\mathrm{CH}_{3}\right.$, OMe). LC-MS: 412.24 [M]. HRMS-ESI $(m / z)[\mathrm{M}+\mathrm{Na}]^{+}$calcd for $\mathrm{C}_{18} \mathrm{H}_{14}{ }^{79} \mathrm{BrN}_{5} \mathrm{NaO}_{2}: 434.02231$, found 434.0225, $[\mathrm{M}+\mathrm{K}]^{+}$calcd for $\mathrm{C}_{18} \mathrm{H}_{14}{ }^{79} \mathrm{BrKN}_{5} \mathrm{O}_{2}: 449.99624$, found 449.9959.

\section{8-Methoxy-2-((1-phenyl-1H-1,2,3-triazol-4-yl)methoxy)quinazoline (11g).}

Reaction of 15 (25 mg, $0.11 \mathrm{mmol})$ with $16 \mathrm{~g}$ (13.90 mg, $0.11 \mathrm{mmol})$ gave 11g: $29.1 \mathrm{mg}$, 74\% yield. mp 168-170 ${ }^{\circ} \mathrm{C}$; FT-IR (KBr, cm$\left.{ }^{-1}\right): 3143,3070,3003,1585,1484,1418,1292,1171,1117,1030,764,690$. ${ }^{1} \mathrm{H}$ NMR (400 $\mathrm{MHz}_{\mathrm{CDCl}}$ ): $\delta 9.24$ (s, $1 \mathrm{H}, H$-quinazoline), 8.48 (s, $1 \mathrm{H}, H$-triazole), 7.76-7.71 (m, $2 \mathrm{H}, H$ ortho of Ph), 7.55-7.49 (m, 2H, $\mathrm{H}$ meta of $\mathrm{Ph}$ ), 7.48-7.38 (m, 3H, $\mathrm{H}$-C6 of quinazoline, $\mathrm{H}-\mathrm{C} 7$ of quinazoline and $\mathrm{H}$ para of $\mathrm{Ph}$ ), 7.23 (dd, $J$ 7.6, $1.3 \mathrm{~Hz}, 1 \mathrm{H}, \mathrm{H}$-C5 of quinazoline), $5.82\left(\mathrm{~s}, 2 \mathrm{H}, \mathrm{CH}_{2}\right), 4.10\left(\mathrm{~s}, 3 \mathrm{H}, \mathrm{CH}_{3}, \mathrm{OMe}\right) .{ }^{13} \mathrm{C} \mathrm{NMR}\left(75 \mathrm{MHz}, \mathrm{CDCl}_{3}\right): \delta$ $163.74(\mathrm{CH}, \alpha$ to $\mathrm{N}$ of quinazoline), 161.64 (C, C2 of quinazoline), $153.83(\mathrm{C}, \mathrm{C} 8$ of quinazoline), 144.40 (C of triazole), 143.57 ( $C, C 8$ a of quinazoline), 137.20 ( $C$ ipso of $\mathrm{Ph}), 129.74(2 \mathrm{CH}$, meta of $\mathrm{Ph}), 128.69(\mathrm{CH}, \mathrm{para}$ of $\mathrm{Ph}), 125.30(\mathrm{CH}, \mathrm{C} 6$ of quinazoline), 122.90 ( $\mathrm{CH}$ of triazole), 122.85 ( $\mathrm{C}, \mathrm{C4a}$ of quinazoline), 120.52 (2CH, ortho of $\mathrm{Ph}), 119.01\left(\mathrm{CH}, \mathrm{C7}\right.$ of quinazoline), $112.88\left(\mathrm{CH}, \mathrm{C5}\right.$ of quinazoline), $61.28\left(\mathrm{CH}_{2}\right), 56.22\left(\mathrm{CH}_{3}, \mathrm{OMe}\right)$. LC-MS: 333.3 [M]. HRMS-ESI $(\mathrm{m} / \mathrm{z})[\mathrm{M}+\mathrm{Na}]^{+}$calcd for $\mathrm{C}_{18} \mathrm{H}_{15} \mathrm{~N}_{5} \mathrm{NaO}_{2}: 356.11179$, found 356.1121, $[\mathrm{M}+\mathrm{K}]^{+}$calcd for $\mathrm{C}_{18} \mathrm{H}_{15} \mathrm{KNN}_{5} \mathrm{O}_{2}: 372.08573$, found 372.0856 .

2-((1-Benzyl-1H-1,2,3-triazol-4-yl)methoxy)-8-methoxyquinazoline (11h). Reaction of 15 (20 mg, $0.093 \mathrm{mmol})$

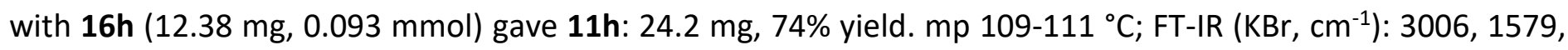
1468, 1414, 1280, 1166, 1117, 1002, 816, 742. ${ }^{1} \mathrm{H} \mathrm{NMR} \mathrm{(300} \mathrm{MHz,} \mathrm{CDCl} 3$ ): $\delta 9.19$ (s, $1 \mathrm{H}, \mathrm{H}$-quinazoline), 7.84 (s, $1 \mathrm{H}, \mathrm{H}$-triazole), 7.43 (dd, J 8.1, $1.4 \mathrm{~Hz}, 1 \mathrm{H}, \mathrm{H}$-C7 of quinazoline), 7.39 (dd, J 8.1, $7.5 \mathrm{~Hz}, 1 \mathrm{H}, \mathrm{H}$-C6 of quinazoline), 7.37-7.32 (m, 3H, $2 \mathrm{H}$ meta and $1 \mathrm{H}$ para of benzyl), 7.29-7.23 (m, 2H, $2 \mathrm{H}$ ortho of benzyl), 7.18 (dd, J 7.5, 1.3 $\mathrm{Hz}, 1 \mathrm{H}, \mathrm{H}$-C5 of quinazoline), $5.71\left(\mathrm{~s}, 2 \mathrm{H}, \mathrm{CH}_{2}\right.$ between $\mathrm{O}$ and triazole), $5.52\left(\mathrm{~s}, 2 \mathrm{H}, \mathrm{CH}_{2}\right.$ of benzyl), $3.99(\mathrm{~s}, 3 \mathrm{H}$, $\mathrm{CH}_{3}, \mathrm{OMe}$ ). ${ }^{13} \mathrm{C} \mathrm{NMR}\left(75 \mathrm{MHz}, \mathrm{CDCl}_{3}\right): \delta 163.63(\mathrm{CH}, \alpha$ to $\mathrm{N}$ of quinazoline), 161.52 (C, C2 of quinazoline), 153.71 ( $C, C 8$ of quinazoline), 144.07 ( $C$ of triazole), 143.49 (C, C8a of quinazoline), 134.54 ( $C$ ipso of Ph), $129.09(2 \mathrm{CH}$, meta of benzyl), $128.73(\mathrm{CH}$, para of benzyl), $128.15(2 \mathrm{CH}$, ortho of benzyl), $125.24(\mathrm{CH}, \mathrm{C6}$ of quinazoline), 124.19 ( $\mathrm{CH}$ of triazole), 122.77 (C, C4a of quinazoline), 118.89 ( $\mathrm{CH}, \mathrm{C7}$ of quinazoline), 112.72 $\left(\mathrm{CH}, \mathrm{C5}\right.$ of quinazoline), $61.32\left(\mathrm{CH}_{2}\right.$ between $\mathrm{O}$ and triazole), $56.12\left(\mathrm{CH}_{3}, \mathrm{OMe}\right), 54.19\left(\mathrm{CH}_{2}\right.$ of benzyl). LC-MS: 347.37 [M]. HRMS-ESI $(\mathrm{m} / \mathrm{z})[\mathrm{M}+\mathrm{Na}]^{+}$calcd for $\mathrm{C}_{19} \mathrm{H}_{17} \mathrm{~N}_{5} \mathrm{NaO}_{2}: 370.12744$, found 370.1277, [M+K] ${ }^{+}$calcd for $\mathrm{C}_{19} \mathrm{H}_{17} \mathrm{KN}_{5} \mathrm{O}_{2}$ : 386.10138, found 386.1013.

8-Methoxy-2-((1-(4-nitrobenzyl)-1H-1,2,3-triazol-4-yl)methoxy)quinazoline (11i). Reaction of 15 (20 mg, $0.093 \mathrm{mmol})$ with $16 \mathrm{i}(16.56 \mathrm{mg}, 0.093 \mathrm{mmol})$ gave $11 \mathrm{i}: 18.4 \mathrm{mg}, 50 \%$ yield. $\mathrm{mp} 179-181^{\circ} \mathrm{C} ; \mathrm{FT}-\mathrm{IR}\left(\mathrm{KBr}, \mathrm{cm}^{-1}\right)$ : $3132,3008,1692,1586,1519,1471,1416,1342,1290,1169,1117,1016,756 .{ }^{1} \mathrm{H}$ NMR $\left(400 \mathrm{MHz}, \mathrm{DMSO}-d_{6}\right): \delta$ 
$9.43\left(\mathrm{~s}, 1 \mathrm{H}, \mathrm{H}\right.$-quinazoline), 8.41 (s, $1 \mathrm{H}, \mathrm{H}$-triazole), 8.21 (half part of an $\mathrm{A}_{2} \mathrm{X}_{2}$ system, $2 \mathrm{H}$ ortho to $\mathrm{NO}_{2}$ of 4 nitrobenzyl), 7.62 (dd, $J 8.1,1.3 \mathrm{~Hz}, 1 \mathrm{H}, \mathrm{H}-\mathrm{C} 7$ of quinazoline), 7.53 (half part of an $\mathrm{A}_{2} \mathrm{X}_{2}$ system with small coupling with $\mathrm{CH}_{2}, 2 \mathrm{H}$ meta to $\mathrm{NO}_{2}$ of 4-nitrobenzyl), 7.48 (dd, J 8.0, 7.9 Hz, $1 \mathrm{H}, \mathrm{H}$-C6 of quinazoline), 7.40 (dd, J 7.9, $1.2 \mathrm{~Hz}, 1 \mathrm{H}, \mathrm{H}$-C5 of quinazoline), 5.81 (s, 2H, $\mathrm{CH}_{2}$ of 4-nitrobenzyl), 5.55 (s, 2H, $\mathrm{CH}_{2}$ between $\mathrm{O}$ and triazole), $3.96\left(\mathrm{~s}, 3 \mathrm{H}, \mathrm{CH}_{3}, \mathrm{OMe}\right) .{ }^{13} \mathrm{C} \mathrm{NMR}\left(100 \mathrm{MHz}, \mathrm{DMSO}-d_{6}\right): \delta 164.22(\mathrm{CH}, \alpha$ to $\mathrm{N}$ of quinazoline), 160.86 (C, C2 of quinazoline), 153.11 ( $C, C 8$ of quinazoline), 147.14 (C, a to $\mathrm{NO}_{2}$ ), 143.28 ( $C$ para to $\mathrm{NO}_{2}$ of 4nitrobenzyl), 142.70 ( $C$ of triazole), 142.32 ( $C, C 8$ a of quinazoline), $128.94\left(2 \mathrm{CH}\right.$, meta to $\mathrm{NO}_{2}$ of 4-nitrobenzyl), $125.73\left(\mathrm{CH}\right.$ of triazole), $125.39\left(\mathrm{CH}, \mathrm{C6}\right.$ of quinazoline), $123.79\left(2 \mathrm{CH}\right.$, ortho to $\mathrm{NO}_{2}$ of 4-nitrobenzyl), $122.35(\mathrm{C}$, C4a of quinazoline), $118.96\left(\mathrm{CH}, \mathrm{C7}\right.$ of quinazoline), $113.54\left(\mathrm{CH}, \mathrm{C5}\right.$ of quinazoline), $60.09\left(\mathrm{CH}_{2}\right.$ between $\mathrm{O}$ and triazole), $55.84\left(\mathrm{CH}_{3}, \mathrm{OMe}\right), 51.84\left(\mathrm{CH}_{2}\right.$ of 4-nitrobenzyl). LC-MS: 392.37 [M]. HRMS-ESI $(\mathrm{m} / z)[\mathrm{M}+\mathrm{Na}]^{+} \mathrm{calcd}$ for $\mathrm{C}_{19} \mathrm{H}_{16} \mathrm{~N}_{6} \mathrm{NaO}_{4}: 415.11252$, found 415.1126, [M+K] ${ }^{+}$calcd for $\mathrm{C}_{19} \mathrm{H}_{16} \mathrm{KN}_{6} \mathrm{O}_{4}$ : 431.08646, found 431.0861.

2-((1-(2,6-Dichlorobenzyl)-1H-1,2,3-triazol-4-yl)methoxy)-8-methoxyquinazoline (11j). Reaction of 15 (25 mg, $0.11 \mathrm{mmol}$ ) with $16 \mathrm{j}(23.57 \mathrm{mg}, 0.11 \mathrm{mmol})$ gave $11 \mathrm{j}: 29.3 \mathrm{mg}, 60 \%$ yield. $\mathrm{mp} 186-188{ }^{\circ} \mathrm{C}$; $\mathrm{FT}-\mathrm{IR}\left(\mathrm{KBr}, \mathrm{cm}^{-1}\right)$ : 3002, 1578, 1426, 1268, 1166, 1114, 1016, 758. ${ }^{1} \mathrm{H} \mathrm{NMR}\left(300 \mathrm{MHz}_{\mathrm{CDCl}}\right.$ ): $\delta 9.19$ (s, $1 \mathrm{H}, \mathrm{H}$-quinazoline), 7.85 (br s, $1 \mathrm{H}, \mathrm{H}$-triazole), 7.44 (dd, $J 8.2,1.7 \mathrm{~Hz}, 1 \mathrm{H}, \mathrm{H}$-C7 of quinazoline), 7.42-7.36 (m, 3H, $2 \mathrm{H}$ ortho to $\mathrm{Cl}$ at 7.38 ppm and $\mathrm{H}$-C6 of quinazoline at $7.40 \mathrm{ppm}), 7.29(\mathrm{dd}, J 9.1,6.8 \mathrm{~Hz}, 1 \mathrm{H}, \mathrm{H}$ meta to $\mathrm{Cl}), 7.19(\mathrm{dd}, J 7.3,1.7 \mathrm{~Hz}, 1 \mathrm{H}$, $\mathrm{H}$-C5 of quinazoline), 5.85 (s, 2H, CH of 2,6-dichlorobenzyl), $5.70\left(\mathrm{~d}, \mathrm{~J} 0.6 \mathrm{~Hz}, 2 \mathrm{H}, \mathrm{CH}_{2}\right.$ between $\mathrm{O}$ and triazole), $4.03\left(\mathrm{~s}, 3 \mathrm{H}, \mathrm{CH}_{3}, \mathrm{OMe}\right) .{ }^{13} \mathrm{C} \mathrm{NMR}\left(75 \mathrm{MHz}, \mathrm{CDCl}_{3}\right): \delta 163.61(\mathrm{CH}, \alpha$ to $\mathrm{N}$ of quinazoline), $161.50(\mathrm{C}, \mathrm{C2}$ of quinazoline), 153.73 ( $C, C 8$ of quinazoline), 143.62 ( $C$ of triazole), 143.53 ( $C, C 8$ a of quinazoline), 136.85 (2C, $\alpha$ to $\mathrm{Cl}), 131.05(\mathrm{CH}$, meta to $\mathrm{Cl}), 130.08(\mathrm{C}, \beta$ to $\mathrm{Cl}), 128.87(2 \mathrm{CH}$, ortho to $\mathrm{Cl}), 125.23(\mathrm{CH}, \mathrm{C} 6$ of quinazoline), 123.76 ( $\mathrm{CH}$ of triazole), $122.78(\mathrm{C}, \mathrm{C4a}$ of quinazoline), $118.89(\mathrm{CH}, \mathrm{C7}$ of quinazoline), $112.71(\mathrm{CH}, \mathrm{C5}$ of quinazoline), 61.39 ( $\mathrm{CH}_{2}$ between $\mathrm{O}$ and triazole), $56.19\left(\mathrm{CH}_{3}, \mathrm{OMe}\right), 49.03\left(\mathrm{CH}_{2}\right.$ of 2,6-dichlorobenzyl). LC-MS: 416.26 [M]. HRMS-ESI $(\mathrm{m} / z)[\mathrm{M}+\mathrm{Na}]^{+}$calcd for $\mathrm{C}_{19} \mathrm{H}_{15}{ }^{35} \mathrm{Cl}_{2} \mathrm{~N}_{5} \mathrm{NaO}_{2}$ : 438.04950, found 438.0495, [M+K] $]^{+}$calcd for $\mathrm{C}_{19} \mathrm{H}_{15}{ }^{35} \mathrm{Cl}_{2} \mathrm{KN}_{5} \mathrm{O}_{2}$ : 454.02344 , found 454.0229 .

\section{Cytotoxicity studies}

Cell culture. Skin normal fibroblastic cells are purchased from Lonza (Basel, Switzerland), HuH7, Caco-2, MDAMB-231, HCT116, PC3, MCF7 and NCl-H727 cancer cell lines were obtained from the ECACC collection (Porton Down, UK). Cells are grown at $37^{\circ} \mathrm{C}, 5 \% \mathrm{CO} 2$ in ECACC recommended media: DMEM for HuH7, MDA-MB-231 and fibroblast, EMEM for MCF7 and CaCo-2, McCoy's for HCT116 and RPMI for PC3 and NCl-H727. All culture media are supplemented by $10 \%$ of FBS, $1 \%$ of penicillin-streptomycin and $2 \mathrm{mM}$ glutamine.

Cytotoxic assay. Chemicals are solubilized in DMSO at a concentration of $10 \mathrm{mM}$ (stock solution) and diluted in culture medium to the desired final concentrations. The dose effect cytotoxic assay of chemical is performed at $25 \mu \mathrm{M}$. Cells are plated in 96 wells plates ( 4000 cells/well). Twenty-four hours after seeding, cells are exposed to chemicals. After $48 \mathrm{~h}$ of treatment, cells are washed in PBS and fixed in cooled $90 \%$ ethanol/5\% acetic acid for 20 minutes and the nuclei are stained with Hoechst 33342 (B2261 Sigma). Image acquisition and analysis are performed using a Cellomics ArrayScan VTI/HCS Reader (ThermoScientific). The survival percentages are calculated as the percentage of cell number after compound treatment over cell number after DMSO treatment.

\section{Protein kinase assays}

Kinase enzymatic activities were assayed in 384-well plates using the ADP-Glo assay kit (Promega, Madison, WI) according to the recommendations of the manufacturer. This assay is a luminescent ADP detection assay that provides a homogeneous and high-throughput screening method to measure kinase activity by quantifying the amount of ADP produced during a kinase reaction. Briefly, the reactions were carried out in a 
final volume of $6 \mu \mathrm{l}$ for $30 \mathrm{~min}$ at $30^{\circ} \mathrm{C}$ in the following buffer: $10 \mathrm{mM} \mathrm{MgCl} 2,1 \mathrm{mM} \mathrm{EGTA}, 1 \mathrm{mM}$ DTT, $25 \mathrm{mM}$ Tris- $\mathrm{HCl} \mathrm{pH} \mathrm{7.5,} 50 \mu \mathrm{g} / \mathrm{ml}$ heparin; with either protein or peptide as substrate in the presence of $10 \mu \mathrm{M}$ ATP. After stopping the kinase reaction, Kinase Detection Reagent was added for one hour at RT. The transmitted signal was then measured using an Envision microplate luminometer (PerkinElmer, Waltham, MA) and expressed in Relative Light Unit (RLU). HsCDK5/p25 (human, recombinant, expressed in bacteria) was assayed on $0.8 \mu \mathrm{g} / \mu \mathrm{l}$ of histone $\mathrm{H} 1$ as substrate. HsCDK9/CyclinT (human, recombinant, expressed by baculovirus in Sf9 insect cells) was assayed on $0.27 \mu \mathrm{g} / \mu \mathrm{l}$ of the following peptide: YSPTSPSYSPTSPSYSPTSPSKKKK, as substrate. HsGSK3 $\beta$ (human, recombinant, expressed by baculovirus in Sf9 insect cells) was assayed on $0.010 \mu \mathrm{g} / \mu \mathrm{l}$ of GS1 peptide, a GSK-3-selective substrate (YRRAAVPPSPSLSRHSSPHQSpEDEEE). HsCK1ع (human, recombinant, expressed by baculovirus in Sf9 insect cells) was assayed on $0.022 \mu \mathrm{g} / \mu \mathrm{l}$ of the following peptide: RRKHAAIGSpAYSITA ("Sp" stands for phosphorylated serine) as CK1-specific substrate. RnDYRK1A-kd (Rattus norvegicus, kinase domain aa 1 to 499, expressed in bacteria, DNA vector kindly provided by Dr. W. Becker, Aachen, Germany) was assayed on $0.033 \mu \mathrm{g} / \mu \mathrm{l}$ of the following peptide: KKISGRLSPIMTEQ as substrate. MmCLK1 (from Mus musculus, recombinant, expressed in bacteria) was assayed on $0.027 \mu \mathrm{g} / \mu \mathrm{l}$ of the following peptide: GRSRSRSRSRSR as substrate. HsPim-1 (human proto-oncogene, recombinant, expressed in bacteria) was assayed on $0.8 \mu \mathrm{g} / \mu \mathrm{l}$ of histone $\mathrm{H} 1$ (Sigma \#H5505) as substrate. HsHaspin-kd (human, kinase domain, amino acids 470 to 798, recombinant, expressed in bacteria) was assayed on $0.007 \mu \mathrm{g} / \mu \mathrm{l}$ of Histone H3 (1-21) peptide (ARTKQTARKSTGGKAPRKQLA) as substrate. Peptide substrates were obtained from Proteogenix (Schiltigheim, France).

\section{Acknowledgements}

We thank Chemveda Life Sciences for providing laboratory facility for carrying these research experiments. This research has been performed also as part of the Indo-French "Joint Laboratory for Natural Products and Synthesis towards Affordable Health". We thank CSIR, CNRS and University of Rennes 1 for their support. AKDB and DB thank Osmania University for financial support through the OU-DST-PURSE-II Programme (20172021). We thank CRMPO (University of Rennes 1) for the high resolution mass spectra analysis. Financial support by the "Ligue contre le Cancer, Conseil Interrégional Grand Ouest" is gratefully acknowledged. The authors thank the Cancéropôle Grand Ouest (axis: natural sea products in cancer treatment), IBiSA (French Infrastructures en sciences du vivant) and Biogenouest (Western France life science and environment core facility network) for supporting KISSf screening facility.

\section{Supplementary Material}

Electronic Supplementary Information (ESI) available: cytotoxic studies of the quinazolines 11 plus copies of the ${ }^{1} \mathrm{H}$ and ${ }^{13} \mathrm{C}$ NMR spectra for all new compounds

\section{References}

1. Michael, J. P. Nat. Prod. Rep. 2007, 24, 223-246 and references cited therein. 
2. Khan, I.; Ibrar, A.; Ahmed, W.; Saeed, A. Eur. J. Med. Chem. 2015, 90, 124-169. https://dx.doi.org/10.1016/j.ejmech.2014.10.084

3. Ajani, O. O.; Audu, O. Y.; Aderohunmu, D. V.; Owalabi, F. E.; Olomieja, A. O. Am. J. Drug Disc. Dev. 2017, 7, 1-24.

https://doi: 10.3923/ajdd.2017.1.24

4. Ji, H.; Dan, H-G.; Rao, G-W. Heterocycl. Commun. 2018, 24, 1-10. https://doi.org/10.1515/hc-2017-0066

5. For a recent review see: Dheer, D.; Singh, V.; Shankar, R. Bioorg. Chem. 2017, 71, 30-54. https:// doi: 10.1016/j.bioorg.2017.01.010

6. Yamamoto, Y.; Shinkai, I., Eds. Science of Synthesis, Thieme Chemistry: Georg Thieme Verlag KG 2004, 2 Hetarenes, Kikelj D. Product class 13: Quinazolines pp 573-749.

7. Aitken, R. A. et al.: 2016 Science of Synthesis: Knowledge Updates 2015/2 DOI: 10.1055/sos-SD-116-01020 Knowledge Updates 2015/216.13.5 Quinazolines (Update 2015).

8. For general reviews on click chemistry see: Kolb, H. C.; Finn, M. G.; Sharpless, K. B. Angw. Chem. Int. Ed. 2001, 40, 2004-2021, and references 9, 10 and 11. https://doi.org/10.1002/1521-3773(20010601)40:11\%3C2004::AID-ANIE2004\%3E3.0.CO;2-5

9. Rostovtsev, V. V.; Green, L. G.; Sharpless, K. B. Ang. Chem. Int. Ed. 2002, 41, 2596-2599. https://doi.org/10.1002/1521-3773(20020715)41:14\%3C2596::AID-ANIE2596\%3E3.0.CO;2-4

10. Tornoe, C. W.; Christensen, C.; Medal, M. J. Org. Chem. 2002, 67, 3057-3064. https:// doi: 10.1021/jo011148j

11. Lutz, J-F. Ang. Chem. Int. Ed. 2008, 47, 2182-2184. https://doi.org/10.1002/anie.200705365

12. Klein, J. E. M. N.; Holzwarth, M. S.; Hohloch, S.; Sarkar, B.; Plietker, B. Eur. J. Org. Chem. 2013, 28, 6310 - 6316. https://doi.org/10.1002/ejoc.201300902 